\title{
New species and new combinations in the genus Swainsona (Fabaceae) in New South Wales
}

\author{
Joy Thompson
}

\begin{abstract}
Thompson, Joy (National Herbarium of New South Wales, Royal Botanic Gardens, Sydney, Australia 2000) 1990. New species and new combinations in the genus Swainsona (Fabaceae) in New South Wales. Telopea 4(1): 1-5. Three species S. queenslandica, S. extrajacens and S. similis are described and the species $S$. bracteata, S. affinis and S. purpurea raised from subspecific rank. The species $S$. formosa is transferred from the genus Clianthus. The affinity of each is discussed and brief notes on habitat and distribution given.
\end{abstract}

Swainsona Salisb. (1806)

1. S. bracteata (Maiden \& Betche) J. Thompson, comb. nov.

BASIONYM: S. greyana var. bracteata Maiden \& Betche (1903: 905).

Holotype: New SOUTH WALES: Central Western Slopes: between Gilgandra and Gummin, W. Forsyth NSW 368, 10.1901 (NSW).

SYNONYM: S. greyana subsp. bracteata (Maiden \& Betche) A.T. Lee (1948: 158).

This species, formerly included in the related S. greyana Lindl., differs from that species in its calyx which, though often densely pubescent, lacks the dense, white woolly, tomentum of that species, and in its longer calyx-lobes and conspicuous bracts. It is found on lighter soils than those of the riverine habitat of $S$. greyana. It is widespread on the western slopes and plains of northern New South Wales and extends northward into Queensland.

\section{S. queenslandica J. Thompson, sp. nov.}

Herba fruticosa perennis usque ad c. $1 \mathrm{~m}$ alta. Foliola 19-25 plerumque peranguste ovata. Racemi usque ad $20 \mathrm{~cm}$ longi floribus c. $15 \mathrm{~mm}$ longis. Calyx lobis tubo brevioribus. Vexillum versus basim callis duobus magnis. Carina anguste obtusa. Stylus angustatus ad apicem. Fructus $25-40 \mathrm{~mm}$ longus c. $15 \mathrm{~mm}$ latus plerumque late ellipticus sutura non intrusa.

Holotype: New SOUTH WALES: North Western Slopes: $9 \mathrm{~km} \mathrm{~W}$. of 'Gunyerwarildi' on Crooble road, K.L. Wilson 2481, 28.11.1982 (NSW). IsOTYPES: BRI, K, MO, L, RSA.

A soft-wooded perennial shrub to a metre or more in height. Stems usually $3-5 \mathrm{~mm}$ or even more in diameter, glabrous or with sparse, fine, irregularly spreading basifixed hairs, mostly $0.5 \mathrm{~mm}$ or less in length. Leaflets 19-25, usually very narrowly ovate, glabrous or almost so, the apex rounded to emarginate, often with a small point. Stipules to c. $3 \mathrm{~mm}$ long, deltoid to long-deltoid, acuminate, joined to form an abaxial ridge, glabrous. Racemes mostly 15-20 cm or more in length, often with c. 20 flowers of various colours (white, pink, or purplish pink to orange-red or dark red), mostly c. 15 $\mathrm{mm}$ long and on minutely puberulous pedicels, the peduncle glabrous or, more usually, with fine crisped hairs and without a pulvinus. Calyx with the tube $2-3 \mathrm{~mm}$ long and the lobes deltoid, obtuse to very shortly acuminate, and much shorter than the tube. Standard c. $15 \mathrm{~mm}$ long and as wide or wider. Wings often $10-15 \mathrm{~mm}$ long, mostly 
oblong or with the apex broader, and usually shortly obtuse. Keel 10-15 mm long and 4-5 mm deep, the apex rather narrowly obtuse and obscurely lipped. Ovary 4-8 $\mathrm{mm}$ long, glabrous, with some hairs near the base or densely partly or wholly pubescent. Style slender beyond the base, thin-textured, tapering to a straight, slender tip, without a tuft of hairs. Fruit $25-40 \mathrm{~mm}$ long and c. $15 \mathrm{~mm}$ wide, usually broadly elliptic, much inflated, the suture not intruded, the funicular tissue evident but very short, the apex almost rounded behind a short beak, the base with a stipe $5-10 \mathrm{~mm}$ long.

This species has been included in the related $S$. galegifolia (Andr) $R$. Br. by most authors. It can be distinguished from $S$. galegifolia by its wing petals, which are approximately equal to, rather than shorter than, the keel, and by its pubescence; and from S. bracteata by its long wing petals and its small bracts. It is common on heavy soils on the north -western slopes of New South Wales and in the Darling Downs district of Queensland, and it extends northward to c. $20^{\circ} \mathrm{S}$ latitude.

The species is named for the fact that it is the most common member of the S. galegifolia-greyana group of species in Queensland. Many Queensland references to S. galegifolia (a species of restricted distribution in Queensland) are based on this taxon.

\section{S. affinis (A.T. Lee) J. Thompson, comb. nov.}

BASIONYM: S. microphylla subsp. affinis A.T. Lee (1948: 256).

Holotype: New SOUTH WALES: North Western Slopes: Dunlop Station, west side of Darling R., Etheridge 10, 7.1903 (NSW).

SYNONYM: S. microphylla subsp. glabrescens A.T. Lee (1948: 255), quoad holotypum (most cited specimens being S. microphylla A. Gray). HolOTYPE: WESTERN AUSTRALIA: near Barrow Range, Camp 33, Elder Exploring Expedition, Helms NSW 717, 17.8.1891. IsOTYPE: $A D$ (pro parte, the sheet at $A D$ cited by Lee including material of $S$. microphylla).

S. microphylla subsp. pallescens A.T. Lee (1948: 255). HOLOTYPE: QUEENSLAND: Herberts Creek, Bowman (MEL). IsOTYPE: NSW 732.

This species differs from the related $S$. microphylla sens. str. in having a slender, variously extended, anvil-shaped style-tip, rather than a truncate tip (see Lee, op. cit.: 258, figs 52a and 52b), and in having fewer leaflets. It is widespread, often in red loamy soil and associated with Callitris and mulga. It is found in all States except Victoria and Tasmania.

\section{S. similis J. Thompson, sp. nov.}

Herba erecta sed adscendens perennis usque ad c. $25 \mathrm{~cm}$ alta. Foliola 5-15 plerumque elliptica. Racemi usque ad c. $25 \mathrm{~cm}$ longi floribus 6-7 mm longis. Calyx lobis tubo aequalibus sed longioribus. Vexillum versus basim cum vel sine lineis crassis vel area crassa. Carina acuta. Stylus vix angustatus ad apicem oblique truncatum. Fructus 6-15 $\mathrm{mm}$ longus 5-8 mm latus ovoideus fere orbicularis sutura intrusa.

HOLOTYPE: NEW SOUTH WALES: North Western Plains: 4 miles $(6 \mathrm{~km}) \mathrm{SW}$ of Brewarrina on Tarcoon road, J. Thompson NSW 87222, 5.9.1968 (NSW).

SYNONYM: S. parviflora var. vestita C.T. White \& Francis (1926: 156). HolotYPE: QueENSLAND: Adavale, W. MacGillivray 991, 28.8.1923 (BRI). IsotyPE: NSW 221. This specimen is somewhat atypical.

An erect or ascending perennial to c. $25 \mathrm{~cm}$ in height. Stems $0.5-1.5 \mathrm{~mm}$ in diameter, with sparse appressed basifixed or subbasifixed hairs less than $0.5 \mathrm{~mm}$ long. Leaflets $5-15$, in general elliptic, often narrowly so, broader and more obtuse near the base of 
the plant, $5-8(->20) \mathrm{mm}$ long, the appressed pubescence usually sparse and confined to the lower surface, the apex obtuse or acute, rarely retuse, with a short point. Stipules 1-6 mm long, deltoid to very long-narrow-deltoid, often failing to form an abaxial ridge but with the petiole tending to form a joint, with sparse hairs on both surfaces. Racemes 10 to almost $25 \mathrm{~cm}$ long, with 5-15 purple flowers 6-7 mm long on pubescent pedicels, the peduncle with scattered minute appressed or divergent antrorse hairs, often dark, and often dense on the upper part, and usually with a distinct dark and pubescent pulvinus. Calyx with the tube c. $2 \mathrm{~mm}$ long and the lobes acuminate-deltoid, variably attenuate and usually almost equal to, or occasionally shorter than the tube. Standard 7-11 mm long and as wide or a little less in width, with or without slender ridges or an amorphous thickening near the base. Wings $5.5-9 \mathrm{~mm}$ long, broadly obovate, the apex much expanded and very shortly obtuse. Keel 5.5-7 mm long and 2.5 $\mathrm{mm}$ deep, the apex acute with a narrow beak-like tip. Ovary $2-2.5 \mathrm{~mm}$ long, with minute hairs over most of the surface but sometimes absent from the lower (nonsutural) side. Style broad at the base, somewhat stiffened above and scarcely or not tapered behind an obliquely truncate tip with a minute tuft of hairs behind it. Fruit $6-15 \mathrm{~mm}$ long and $5-8 \mathrm{~mm}$ wide, shortly ovoid or oblong-elliptic, to almost round, inflated but dorsiventrally compressed, the suture intruded, the funicular tissue short or minimal, the apex broadly and obliquely rounded below a short beak, the base with a minute stipe.

This species has affinities with S. recta A.T. Lee but differs in lacking an abaxial stipular ridge, having calyx-lobes as long as or longer than the tube and having a pulvinus at the base of its peduncle. It differs from $S$. parviflora Benth. in habit, being erect or ascending rather than prostrate. The species is found on red soil in grassland or open woodland on the western plains of New South Wales and in inland parts of southern Queensland.

It is named for its similarity to these related species.

\section{S. extrajacens J. Thompson, sp. nov.}

Herba erecta probabiliter annua usque ad c. $30 \mathrm{~cm}$ alta. Foliola 9-21, ovata vel ovatoelliptica. Racemi usque ad c. $15 \mathrm{~cm}$ longi floribus $6-8 \mathrm{~mm}$ longis. Calyx lobis tubo brevioribus. Vexillum versus basim area crassa bilobata. Carina apice anguste acuta et elevata. Stylus lato basi parvus angustatus apice lato. Fructum maturum non vidi.

HolotyPE: NEW SOUTH WALES: North Far Western Plains: 'Narriearra', L. Richley SCS 1482, 4.7.1974 (NSW).

An erect, apparently annual plant from 10 to c. $30 \mathrm{~cm}$ tall. Stems mostly $2-4 \mathrm{~mm}$ in diameter, with rather sparse, fine, mostly spreading, often irregularly crisped, basifixed hairs c. $0.75 \mathrm{~mm}$ long. Leaflets 9-21 (fewer on younger plants), ovate to ovate-elliptic, mostly 10-15 mm long (often wider at the base of the plant), with a loose pubescence often restricted to the margins on the upper surface, the apex retuse to emarginate, often recurved with a short point. Stipules c. $5 \mathrm{~mm}$ long, mostly narrowly lanceolate above a broad base, not joined in an abaxial ridge, the pubescence on both sides but mostly near the margins. Racemes $5-\mathrm{c} .15 \mathrm{~cm}$ long, with 5-10 purple flowers $6-8 \mathrm{~mm}$ long, on densely pubescent pedicels, the peduncle with a sparse spreading pubescence often more antrorse and dense in the upper part, and without a pulvinus. Calyx with the tube c. $2 \mathrm{~mm}$ long and the lobes deltoid-acuminate and shorter than the tube. Standard 8-9 $\mathrm{mm}$ long and a little wider, with a 2-lobed prominent thickening near the base. Wings 7-8 $\mathrm{mm}$ long, obovate, with the apex very shortly obtuse. Keel 6-8 $\mathrm{mm}$ long and c. $2.5 \mathrm{~mm}$ deep, the apex narrowly acute and upcurved so that the narrow beak-like tip is well behind the end. Ovary c. $3 \mathrm{~mm}$ long, glabrous or with a few long hairs near the base. Style tapering slightly and evenly from a rather broad base that 
extends above the ovary-tip, not much thickened, the stigmatic end rather broad and sometimes bent to one side, with a forwardly directed tuft or line of minute hairs just behind it. Fruit not seen mature.

This eremaean species of obscure affinity was referred to as Swainsona sp. A. in Jacobs \& Pickard (1981). It is found with annual saltbushes in the north-western corner of New South Wales and the adjacent part of eastern South Australia.

It is named for its location remote from populated areas.

\section{S. purpurea (A.T. Lee) J. Thompson, comb. nov.}

BASIONYM: S. stipularis var. purpurea A.T. Lee (1948: 213).

Holotype: South Australia: Camp 41, between the Warburton River and Lake Eyre, near Poonarunna homestead (ruins), Simpson Desert Expedition, 28.7.1935 (AD).

SYNONYM: S. stipularis var longialata A.T. Lee (1948: 213). HOLOTYPE: NEW SOUTH WALES: North Far Western Plains: Bulloo Overflow, N.C.W. Beadle NSW 613, 12.8.1941 (NSW).

This species differs from S. stipularis F. Muell. especially in its narrow and entire stipules, its slender and tapering style and its purple (as opposed to usually orange) flowers. Usually associated with margins of salt and/or gypsum lakes, it is a variable species extending from far western New South Wales and the south-western corner of Queensland to Western Australia.

\section{S. formosa (G. Don) J. Thompson, comb. nov.}

BASIONYM: Donia formosa G. Don (1832: 468).

Holotype: Western Australia: North-west coast of New Holland at the Curlew River, King (BM, n.v.).

SYNONYM: Clianthus formosus (G. Don) Ford \& Vickery (1950: 302). For further synonymy see Ford and Vickery, op. cit.: 303.

This species, widespread from inland areas of western New South Wales to the coast of Western Australia, has little affinity with Swainsona species of eastern Australia but is related to several in Western Australia. It is closely related to $S$. beasleyana $F$. Muell. from which it differs in its larger usually red (not purple) flowers, acute keel and longer fruit. Its former inclusion in the New Zealand genus Clianthus Soland. ex Lindl. was based on a superficial floral resemblance rather than close affinity. This taxon differs from the single species of Clianthus in its restricted inflorescence, its well-developed calyx-lobes, its narrow, long, cylindrical and bilocular pods, its pubescence of fine spreading hairs, its large, broad, pubescent, toothed stipules and its prostrate habit.

\section{References}

Don, G. (1832) A General History of the Dichlamydeous Plants 2 (J.G. \& F. Rivington et al.: London) Ford, N.C., \& Vickery, J.W. (1950) The correct name of Sturt's Desert Pea, Clianthus formosus (G. Don) comb. nov. Contr. New South Wales Natl. Herbarium 1(5): 302-303.

Jacobs, S.W.L., \& Pickard, J. (1981) Plants of New South Wales (Government Printer: Sydney) Lee, A.T. (1948) The Genus Swainsona. Contr. New South Wales Natl. Herbarium 1(4): 131-271. 
Maiden, J.H., \& Betche, E. (1903) Notes from the Botanic Gardens, Sydney, No. 9. Proc. Linn. Soc. New South Wales 28: 904-923.

Salisbury, R.A. (1806) The Paradisus Londinensis (William Hooker: London)

White, C.T. \& Francis, W.D. (1926) Contributions to the Queensland Flora, No. 3. Proc. Roy. Soc. Queensland 37: 152-167.

Manuscript received 28 July 1989

Manuscript accepted 15 December 1989 